\title{
Estimating the Small Strain Stiffness of Peat Soil Using Geophysical Methods
}

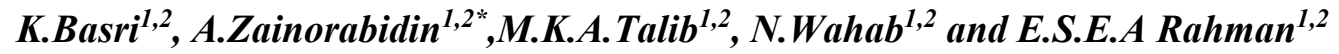 \\ ${ }^{1}$ Faculty of Civil Engineering and Built Environment, Universiti Tun Hussein Onn Malaysia, Johor, 86400 Parit \\ Raja, Johor \\ ${ }^{2}$ Research Centre for Soft Soil (RECESS), Universiti Tun Hussein Onn Malaysia, Johor, 86400 Parit Raja, \\ Johor \\ *Email: adnanz@uthm.edu.my
}

\begin{abstract}
Geotechnical design commonly requires that the in-situ stiffness, strength and permeability of the ground be obtained. Laboratory based investigation often related with risk of sample disturbance and difficulties to replicate the in-situ stress condition which results in overestimation or underestimation. Application of geophysical methods in geotechnical investigation previously was limited to targeting and dimensioning sub-surface features due to lack of resolution. However, rapid developments of geophysical methods result in the application of these methods in providing geotechnical design parameters. Multichannel analysis of surface waves (MASW) and seismic refraction were among the geophysical methods capable of obtaining stiffness parameters including the maximum shear modulus $\left(\mathrm{G}_{\max }\right)$ and maximum elastic modulus $\left(\mathrm{E}_{\max }\right)$. The study revealed the efficiency of these methods to measure the small strain stiffness of peat soil with high accuracy as the results obtained were found to be similar to those obtained by previous researchers. Overall, the $\mathrm{G}_{\max }$ and $\mathrm{E}_{\max }$ values of peat soil obtained range from 0.50 to $1.92 \mathrm{MPa}$ and 1.45 to $5.71 \mathrm{MPa}$ respectively. The $\mathrm{G}_{\max }$ and $E_{\max }$ values obtained shows significant increase with depth governed primarily by the effective stress. Other parameters such as degree of decomposition and peat thickness also shows potential influence on the $\mathrm{G}_{\max }$ and $\mathrm{E}_{\max }$ values obtained.
\end{abstract}

Indexed Terms- Peat soil, shear-wave velocity, primary-wave velocity, stiffness, active MASW, seismic refraction, maximum shear modulus, maximum elastic modulus.

\section{INTRODUCTION}

Traditionally geophysical method has been used as indirect means of investigating sub-surface features. The application for engineering site investigation has been only marginally successful in engineering site investigations. The reasons include lack of resolution, poor choice of geophysical method and underdevelopment of processing software. However, in recent years rapid development have taken place in geotechnical engineering investigation resulting in application of geophysical methods to provide design parameters. In particular, there is a growing admiration of measuring the small-strain stiffness, using seismic methods [1-5]. There are also increasing correlation between the seismic waves (i.e. $V_{s}$ and $V_{p}$ ) with geotechnical parameters such as undrained shear strength [6-8], SPT-N value [9], cone penetration parameters [10-13], and 1D compression parameters [13, 14]. The growing interest of geophysical method application in geotechnical investigation has the advantages of not being affected by sampling disturbance and insertion effects. The stiffness parameters obtained in the laboratory were generally low due to sample disturbance [15]. Thus, excessive sample disturbance risk underestimation or overestimation of the geotechnical design. An example of application of stiffness parameters include deformation analyses and ground movements. In soft soil investigation such as peat soil, the effect of sample disturbance was critical due to the presence of fibre and very high water content. The peat soil also has high permeability and low shear strength causing difficulties maintaining high quality undisturbed sample [16]. Application of geophysical method provide alternative way of obtaining the 
peat soil parameters using field measurement which allows the investigation done in it's natural state. Field measurement allows the mitigation of the effect of sample disturbance caused by boring, tube insertion, extraction, transportation, storage, trimming and reconsolidation [17, 18]. Therefore, the determination of peat soil geotechnical parameters can significantly be improved for better design accuracy.

With the aim of providing helpful geotechnical information to engineers and designers for practical works on peat soil ground, this paper attempted to determine stiffness parameters which include $G_{\max }$ and $E_{\max }$ values in southern peninsular Malaysia. The $\mathrm{G}_{\max }$ and $\mathrm{E}_{\max }$ values were computed using shearwave velocity $\left(\mathrm{V}_{\mathrm{s}}\right)$ and primary-wave velocity $\left(\mathrm{V}_{\mathrm{p}}\right)$ obtained using geophysical methods.

\section{MATERIAL AND METHODS}

\subsection{Overview of peat soil in study locations}

Overall there are approximately 2.4 million hectares of peatlands which covers about $7.45 \%$ of Malaysia's total land area. The largest and thickest peatlands are located within the state of Sarawak which is around $69.08 \%$ of the total peatlands in Malaysia [19]. The peat thickness can reach up to 20 $\mathrm{m}$ especially in the inland area [20]. The remaining peatlands are located in Peninsular Malaysia and Sabah with total land area of $26.16 \%$ and $4.76 \%$ correspondingly [19]. The state of Johor in Peninsular Malaysia covers around 143,974 ha of peatlands. The peatlands are mostly distributed near the coastal area (see Figure 1).

The study was conducted at Parit Nipah (PNPt), Pontian (PPt) and Medan Sari (MSPt), in the state of Johor as shown in Figure 1. The locations were chosen as all three sites represent different classification of peat thickness. According to the peat sampler investigation, the peat thickness at Medan Sari, Pontian and Parit Nipah were $1.5 \mathrm{~m}, 3.0 \mathrm{~m}$ and $4.0 \mathrm{~m}$ respectively [21]. The peat soil at Medan Sari, Pontian and Parit Nipah were classified as shallow peat $(<1.5 \mathrm{~m})$, moderate deep peat $(1.5$ to $3 \mathrm{~m})$, deep peat $(>3 \mathrm{~m})$ correspondingly. The index properties of peat soil in the study areas were as shown in Table 1. Both Pontian and Parit Nipah peat were categorized as hemic peat with Von Post scale of H5 to H6. Similarly, Wahab et al. [22] also classified Parit Nipah peat as hemic peat with Von Post scale of H5. While, Medan Sari was grouped as fibric peat according to the fibre content classification by US Department of Agriculture (USDA). The classification however is based on the undisturbed samples obtained approximately $1 \mathrm{~m}$ from the surface. There are findings that shows the peat type might change with depth especially at thicker peat soil layer. As mentioned by Huat et al. [23] and Ulusay et al. [24], peat soil which is categorized as $\mathrm{H} 3$ and $\mathrm{H} 4$ near the surface, with increasing depth it would be classified as $\mathrm{H} 5$ to $\mathrm{H} 7$. The moisture content and organic content range from 839.7 to $913.2 \%$ and 76.7 to $96.8 \%$ correspondingly. Higher moisture content recorded at Medan Sari could be due to the lower decomposition rate compared to other locations. As mentioned by Kazemian [25], the more fibrous peat, the higher is the water content. The liquid limit and specific gravity range between 255 to $425 \%$ and 1.24 to 1.34 respectively. The peat soil at the locations were acidic with $\mathrm{pH}$ value range between 3.7 to 4.0 .

\subsection{Multichannel Analysis of Surface Waves (MASW)}

The surface waves investigation was conducted using active MASW method. The method is introduced in the late 1990s by researchers at the Kansas Geological Survey (KGS). The entire process involves three steps: acquisition of ground roll, construction of dispersion curve, and backcalculation (inversion) of the $V_{s}$ profile from the calculated dispersion curve [26]. Three survey lines were investigated at Parit Nipah and Pontian with $5 \mathrm{~m}$ offset from each survey line. At Medan Sari, only a single survey line was investigated. The field surveys were conducted using 24 geophones with natural frequency of $4.5 \mathrm{~Hz}$ arranged linearly. Figure 2 shows the general field arrangement for the active MASW field survey. The receiver spacing $(\mathrm{dx})$ used was $1 \mathrm{~m}$, producing total spread length $(\mathrm{L})$ of $23 \mathrm{~m}$. Sampling time of 
approximately $4 \mathrm{~s}$ was used with $250 \mu$ s sampling interval and 16384 number of samples. A $7 \mathrm{~kg}$ sledgehammer was used as active source coupled with rubber plate. The rubber plate was chosen rather than the conventional steel plate to minimized the effect of plate penetrating the soft peat ground during impact and increase the resolution at lower frequencies [27, 28]. The distance of the optimum source offset $\left(\mathrm{X}_{1}\right)$ for the peat soil condition obtain from the preliminary investigation was half the total spread length (L/2) which was $11.5 \mathrm{~m}$. Due to the characteristics of peat soil, longer source offset should be prevented due to rapid attenuation of seismic energy which contribute to low signal-to-noise ratio [29]. Park and Shawver [30] also mentioned that, longer source offset ensures the recording of long wavelengths, but results in lack of short wavelength due to excessive attenuation. The source offset distance was important to prevent interference of near and far-field effects which results in either overestimation or underestimation of measurements [31]. Five stackings were used for each dataset to increase the signal-to-noise ratio and suppress the ambient noise. The data obtained were processed using the SeisImager and WaveEq softwares.

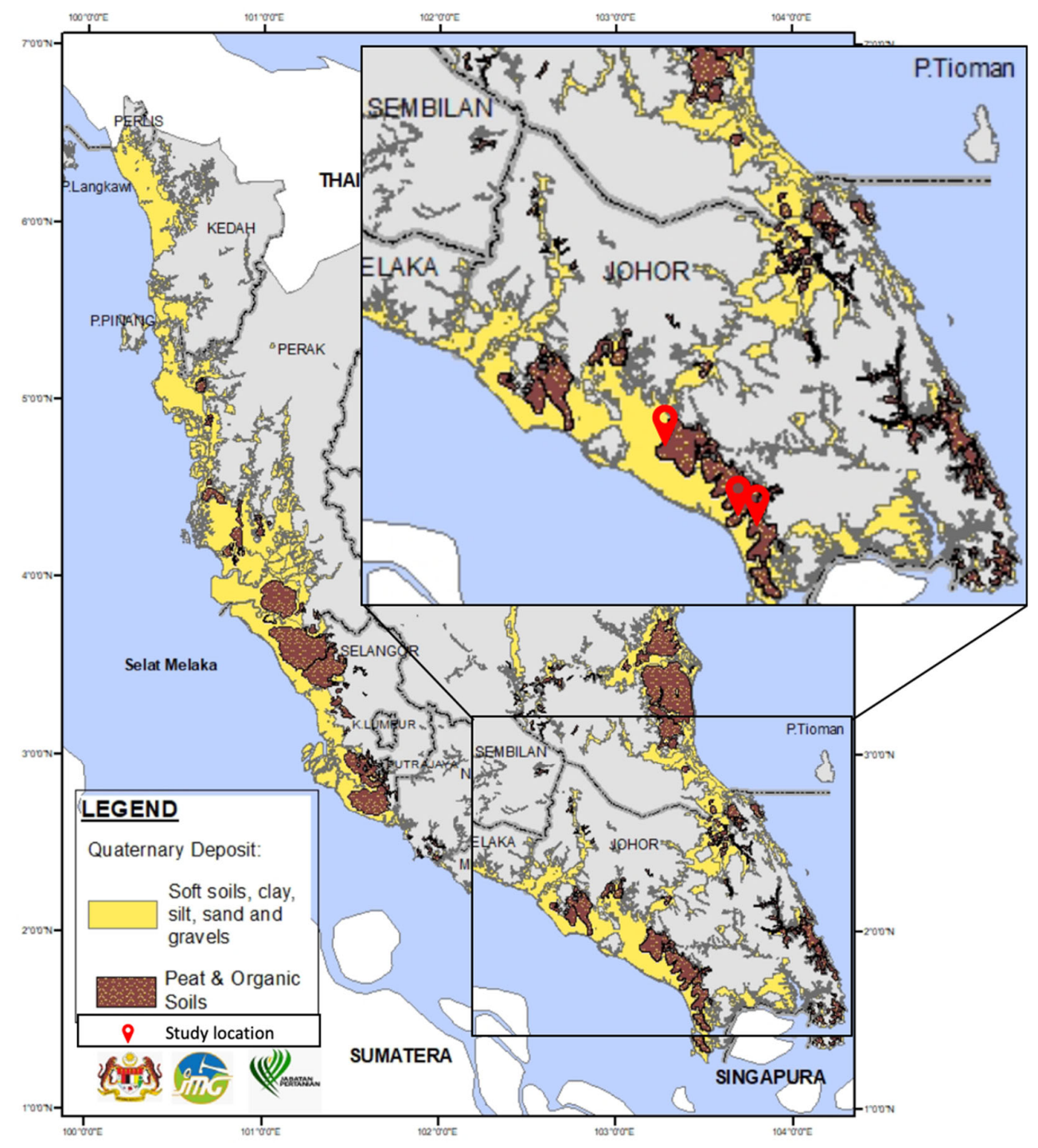

Figure 1: Geological map of the study area [32] 
The shear-wave velocity $\left(\mathrm{V}_{\mathrm{s}}\right)$ profiles obtained were than computed using Equation 1 to estimate the maximum shear modulus $\left(\mathrm{G}_{\max }\right)$ value of peat soil at low strain levels $(<0.001 \%)$. The bulk density $(\rho)$ was obtained using the peat sampler equipment. It was recorded for every $0.5 \mathrm{~m}$ interval until the peat soil layer ends. The procedures of the peat sampler investigation follows the peat sampler operating instruction [33].

$G_{\max }=\rho V_{s}^{2}$

Where, $\rho$ is bulk density, $V_{s}$ is shear-wave velocity and $G_{\max }$ is maximum shear modulus.

Table 1: Index properties of peat soil at Parit Nipah, Pontian and Medan Sari, Johor

\begin{tabular}{lccc}
\hline Properties & PNPt & PPt & MSPt \\
\hline Moisture content (\%) & 839.7 & 898.9 & 913.2 \\
Liquid limit (\%) & 345 & 255 & 425 \\
Organic content (\%) & 81.8 & 76.7 & 96.8 \\
Specific gravity & 1.34 & 1.28 & 1.24 \\
Fibre content (\%) & 47.6 & 43.6 & 73.9 \\
pH & 4.0 & 3.7 & - \\
Von post scale & H6 & H5 & - \\
Peat type & Hemic & Hemic & Fibric \\
References & Author & Zainorabidin and Zolkefle [34] & Author \\
\hline
\end{tabular}

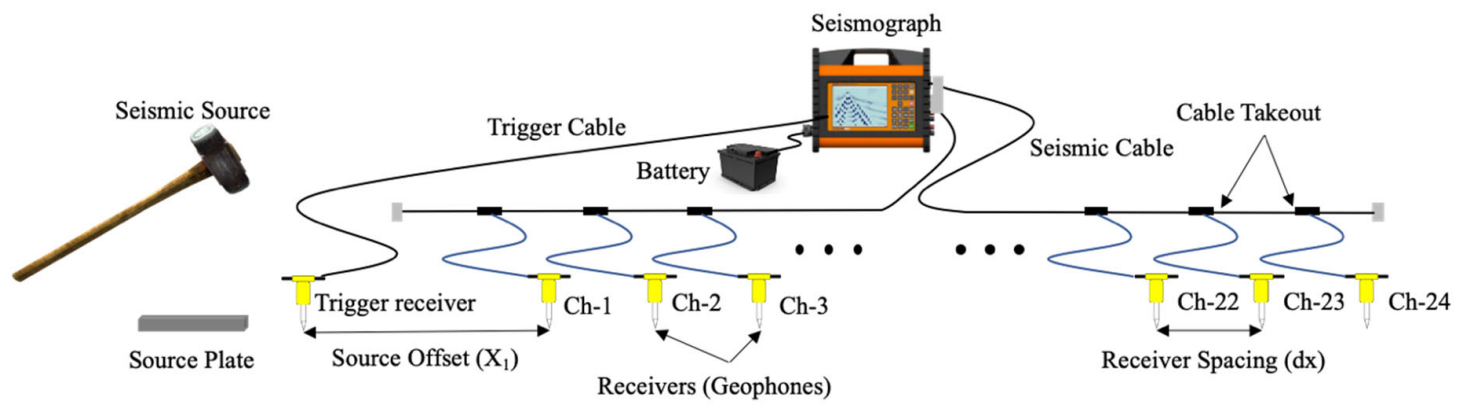

Figure 2: General field arrangement for active MASW survey

\subsection{Seismic Refraction}

The seismic refraction surveys were conducted only at Parit Nipah and Pontian. The field arrangements and equipment were similar as the active MASW method. However, some field parameters were changed which include the geophone sensors, impact source location and recording time. Higher natural frequency geophones which is $28 \mathrm{~Hz}$ were used instead of $4.5 \mathrm{~Hz}$ to allow recording of higher 
frequencies. The seismic refraction survey also requires 7 shot point locations, compared to a single shot point in active MASW method. The locations of the shot point are at both offsets, between $1^{\text {st }}$ and $2^{\text {td }}, 6^{\text {th }}$ and $7^{\text {th }}, 12^{\text {th }}$ and $13^{\text {th }}, 18^{\text {th }}$ and $19^{\text {th }}$ and $23^{\text {rd }}$ and $24^{\text {th }}$ geophone. The sampling interval time and number of samples used were $500 \mu$ s and 2048 respectively, resulting a total recording time of $1.2 \mathrm{~s}$. Shorter recording time was used compared to active MASW method as only the first arrival was needed for the data processing of seismic refraction method. The data obtained were processed using Pickwin and Plotrefa modules.

The data process using the software mentioned results in a 2-Dimensional primary-wave velocity $\left(\mathrm{V}_{\mathrm{p}}\right)$. However, a 1-Dimensional primary-wave velocity was required for the computation of Poisson's ratio and maximum elastic modulus using Equation 2 and Equation 3. Therefore, a 1-Dimensional primary-wave velocity profiles were extracted from the midpoint of each survey lines. The midpoint of the survey line was chosen as all the other parameters were also extracted at similar location.

$$
\begin{aligned}
& v=0.5\left[\frac{\left(\frac{V p}{V_{s}}\right)^{2}-2}{\left(\frac{V p}{V_{s}}\right)^{2}-1}\right] \\
& E_{\max }=2 G_{\max }(1+v)
\end{aligned}
$$

Where, $v$ is Poisson's ratio, $\mathrm{V}_{\mathrm{p}}$ is primary-wave velocity and $\mathrm{E}_{\max }$ is maximum elastic modulus

\section{RESULTS AND DISCUSSION}

\subsection{Shear-wave velocity and primary-wave velocity profiles of peat soil}

The shear-wave velocity $\left(\mathrm{V}_{\mathrm{s}}\right)$ of peat soil obtained using active MASW method at all locations were as shown in Figure 3. There were three $V_{s}$ profiles each for Parit Nipah and Pontian, including a single $V_{s}$ profile for Medan Sari. Overall, the $\mathrm{V}_{\mathrm{s}}$ values determined were very low which could be governed by the characteristics of peat soil which include very high water content, high organic content, high compressibility and low shear strength [35]. The graph also shows that, the $\mathrm{V}_{\mathrm{s}}$ values of peat soil increases only slightly from the surface up until about $1 \mathrm{~m}$ before the transition layer to marine clay, where the $V_{s}$ values increase significantly. This behaviour could be attributed by the low bulk density and high water table on peat soil. As mentioned by Huat [36], there is only slight tendency for an increase in peat soil strength with depth due to very low bulk density and high water table. The peat soil profiles obtained using peat sampler at all locations revealed that the highest bulk density of peat soil determined was only $1430 \mathrm{~kg} / \mathrm{m}^{3}$, while the water table was approximately $0.5 \mathrm{~m}$ from the surface. The peat soil profiles also delineated that the peat soil near the surface was less humified compared to peat soil at deeper depth. Thus, the $\mathrm{V}_{\mathrm{s}}$ values of peat soil were expected to decrease with depth as lesser humified peat soil layer have greater strength and much more stiff compared to highly humified peat soil layer, thus, giving higher $\mathrm{V}_{\mathrm{s}}$ value $[17,25,37]$. However, the graph shows otherwise as the $\mathrm{V}_{\mathrm{s}}$ values shows increasing trend with depth. This behaviour could be governed by the increase of effective stress with depth. As the $V_{s}$ value increases with the increase of effective stress [14]. This condition suggests that the in-situ $V_{s}$ value was primarily governed by the effective stress rather than the degree of decomposition rate. While, the sudden significant increase near the transition layer could be governed by the rapid increase in effective stress approaching the marine clay layer.

The influence of decomposition rate was further investigated by comparing the peat soil $\mathrm{V}_{\mathrm{s}}$ value of hemic peat (Parit Nipah and Pontian) and fibric peat (Medan Sari). The results exposed that the $V_{s}$ values at Medan Sari peat were slightly higher compared to Pontian peat, which in good agreement with the previous assumptions where lesser humified peat soil has higher $V_{s}$ value. The higher $V_{s}$ values could be governed by fresh (intact) fibres in lesser humified peat compared to completely decomposed (amorphous) material in more humified peat [38]. As mentioned by Sarkar and Sadrekarimi [39], 
strength of peat is largely associated with the presence of organic fibres. However, the $V_{s}$ values of Parit Nipah peat soil was slightly higher compared to Pontian and Medan Sari which raised speculation that the peat thickness could also affect the $V_{s}$ value determined. The results however were very limited to fully understand the influence of decomposition rate and peat thickness on the generated $V_{s}$ value. Overall, the effective stress shows more prominent influence on the generated $V_{s}$ value of peat soil with depth. The $\mathrm{V}_{\mathrm{s}}$ value obtained for Parit Nipah, Pontian and Medan Sari were range from 28.7 to 33.9 $\mathrm{m} / \mathrm{s}, 25.4$ to $36.6 \mathrm{~m} / \mathrm{s}$ and 27.3 to $34.2 \mathrm{~m} / \mathrm{s}$.

The seismic refraction investigation allowed the determination of primary-wave velocity $\left(\mathrm{V}_{\mathrm{p}}\right)$. The 2-Dimensional $V_{p}$ profiles obtained from the investigation were further analysed by extracting the 1Dimensional $V_{p}$ profiles on the centre line. For this investigation, only Parit Nipah and Pontian peat soil were included with three $V_{p}$ profiles for each location. Figure 4 shows the $V_{p}$ profiles obtained on both locations. Generally, the $V_{p}$ values increases slightly with depth for both locations. This behaviour was governed by the increasing effective stress and decreasing void ratio of peat soil with depth. As mentioned earlier, peat soil layer at deeper depth was more humified compared to the peat soil layer near the surface. According to Kazemian [25], the more fibrous the peat soil, the higher the void ratio. This suggest that the void ratio of peat soil decreases with depth which contribute to increases in $V_{p}$ value with depth. While, slightly lower $V_{p}$ values were recorded near the surface which was due to the layer was on top of the ground water table. The measured ground water table on both locations were approximately $0.5 \mathrm{~m}$ from the surface. According to Foti [3], other than the soil skeleton, the $\mathrm{V}_{\mathrm{p}}$ value was more influence by the compressibility of the pore fluid. This suggest that dry peat soil have lower $V_{p}$ value than saturated peat soil. Furthermore, approaching the transition layer to marine clay, the $V_{p}$ values increases significantly. This behaviour was similar with the trend shown by the $V_{s}$ value which suggest that the effective stress at the transition layer increases drastically shown by the rapid increase in both $V_{s}$ and $V_{p}$ value. Overall, the $V_{p}$ value obtained for Parit Nipah and Pontian range from 99.1 to $291.6 \mathrm{~m} / \mathrm{s}$ and 98.2 to $244.1 \mathrm{~m} / \mathrm{s}$ correspondingly,

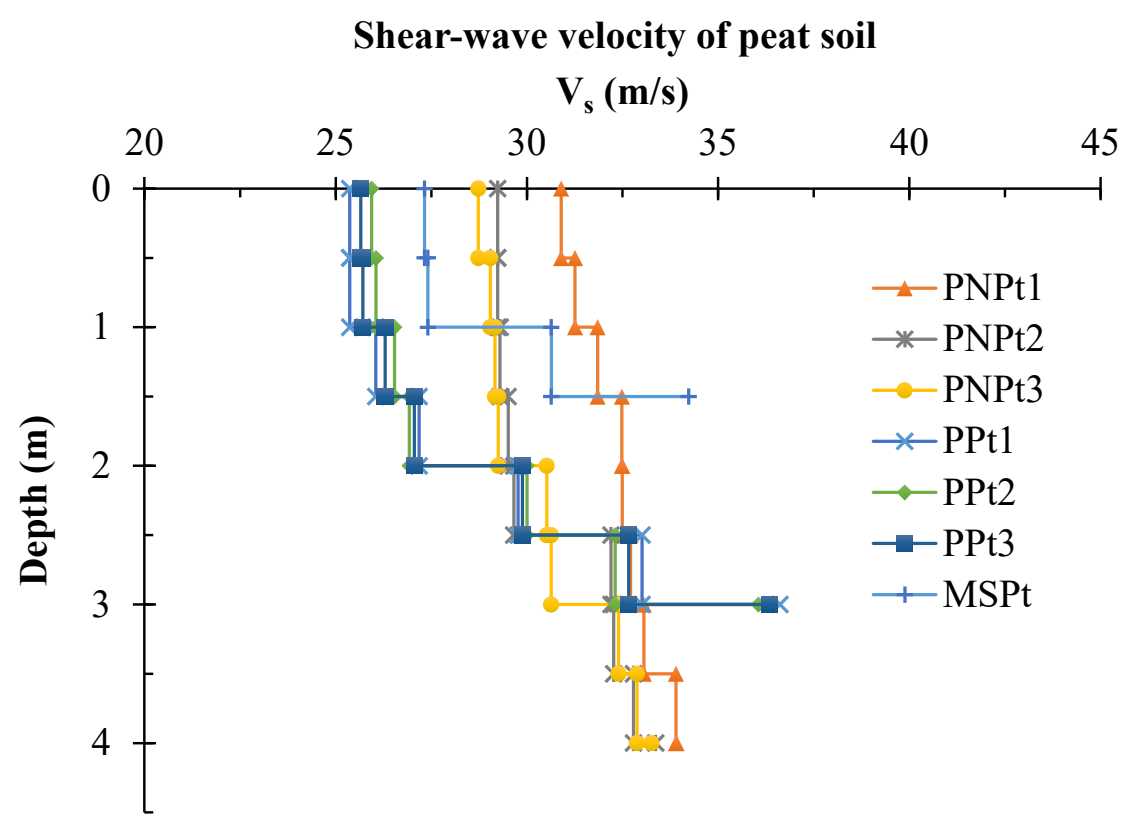

Figure 3: Shear-wave velocity profiles of peat soil at Parit Nipah, Pontian and Medan Sari 


\subsection{Maximum shear modulus and maximum elastic modulus profiles of peat soil}

The stiffness parameters which include the maximum shear modulus $\left(\mathrm{G}_{\max }\right)$ and maximum elastic modulus $\left(E_{\max }\right)$ were determined using geophysical investigation combine with mathematical equations. The maximum shear modulus $\left(\mathrm{G}_{\max }\right)$ was obtained through the relationship between the shear-wave velocity and bulk density as shown in Equation 1. While, the maximum elastic modulus $\left(E_{\max }\right)$ was obtained by the relationship of Poisson's ratio and $G_{\max }$ as described in Equation 3. The Poisson's ratio was generated by Equation 2 by the relationship between $V_{s}$ and $V_{p}$ values. The bulk density of peat soil was obtained using peat sampler at the midpoint of the survey lines at all locations. The bulk density of peat soil at Parit Nipah, Pontian and Medan Sari range from 734 to $1255 \mathrm{~kg} / \mathrm{m}^{3}, 770$ to $1430 \mathrm{~kg} / \mathrm{m}^{3}$, and 1100 to $1330 \mathrm{~kg} / \mathrm{m}^{3}$ respectively. The bulk density was obtained at the midpoint of the survey line because the generated $\mathrm{V}_{\mathrm{s}}$ value was also located at similar location. As mentioned by Luo et al. [40], the inverted 1-Dimensional $V_{s}$ profile should be located at the midpoint of the survey line. Figure 5 and Figure 6 summarizes the $\mathrm{G}_{\max }$ and $\mathrm{E}_{\max }$ values of peat soil at Parit Nipah and Pontian. Overall, the graph shows slight increases of $G_{\max }$ and $E_{\max }$ values with depth on both locations. Similar finding was obtained by Abbiss [1] and Donohue et al. [41], where the stiffness modulus tend to increase with depth. Slight variations were also observed especially on the top $1 \mathrm{~m}$ which could be due to the heterogeneity of peat soil. The variations however were small and negligible as clear increasing pattern with depth was observed. The degrading effects and increases of decomposition rate with depth also contributed to the increasing $\mathrm{G}_{\max }$ and $\mathrm{E}_{\max }$ values with depth. According to Matthews et al. [42] and Kishida et al. [43], degrading effect of weathering, decrease in organic content, increase in effective stress and stress relief will generally cause the $G_{\max }$ and $E_{\max }$ values to increase significantly. The $G_{\max }$ values obtained for Parit Nipah and Pontian range from 0.63 to $1.40 \mathrm{MPa}$ and 0.50 to $1.92 \mathrm{MPa}$ respectively. While, The $\mathrm{E}_{\max }$ values were ranging from 1.82 to $4.17 \mathrm{MPa}$ and 1.45 to $5.71 \mathrm{MPa}$ for Parit Nipah and Pontian correspondingly.

Primary-wave velocity of peat soil

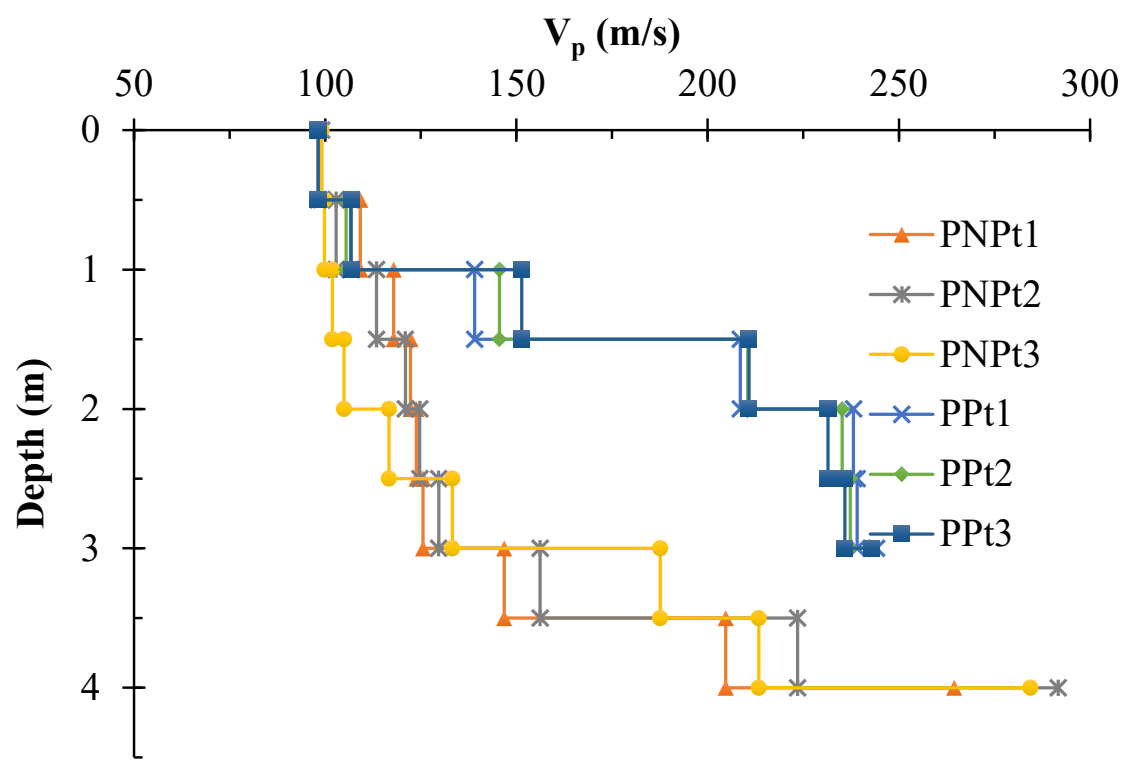

Figure 4: Primary-wave velocity profiles of peat soil at Parit Nipah and Pontian 


\section{CONCLUSIONS}

The application of geophysical methods for the determination of stiffness parameters such as the $G_{\max }$ and $\mathrm{E}_{\max }$ values shows promising findings. The ability of the geophysical methods to investigate the geotechnical parameters in-situ eliminates the risk of sample disturbance commonly face for laboratory

\section{Maximum shear modulus $\left(G_{\text {max }}\right)$ value of peat soil}

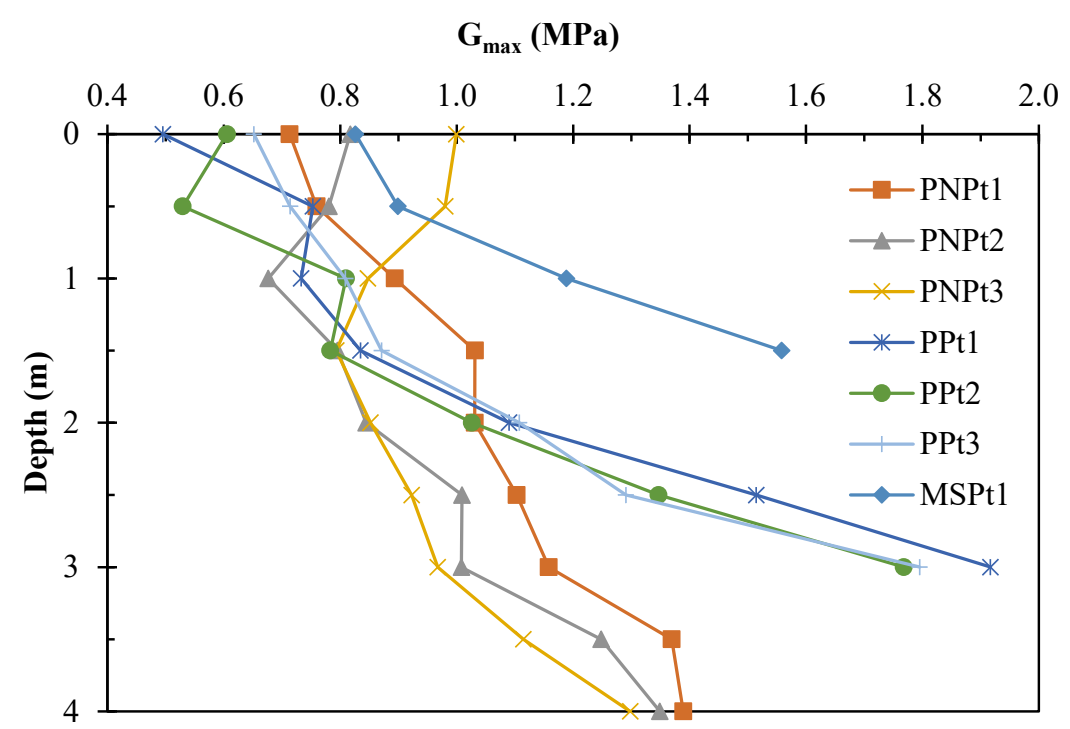

Figure 5: Maximum shear modulus profiles of peat soil at Parit Nipah, Pontian and Medan Sari

\section{Maximum elastic modulus $\left(E_{\max }\right)$ value of peat soil}

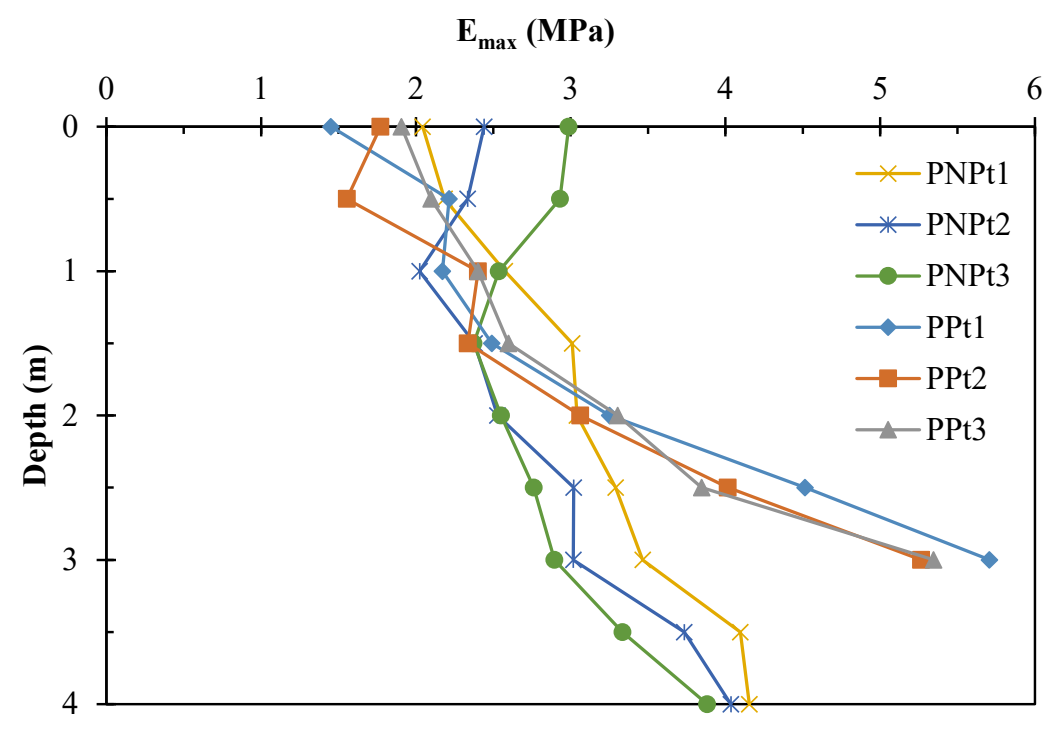

Figure 6: Maximum elastic modulus profiles of peat soil at Parit Nipah and Pontian 
investigation. Problems usually encountered includes boring, tube insertion, sample extraction, transportation, storage, trimming and reconsolidation. The presence of fibre in peat soil further complicates the sample retrieval as the peat fibres usually interfere during tube insertion causing major sample disturbance. The excessive loss of water content also could affect the results as peat soil was well known to store very high water content. Although, there were still very limited data obtained, it is expected that these data could provide quantitative information for geotechnical applications or act as a preliminary data for further investigation on peat soil. Correlation between the seismic parameters with geotechnical parameters were also possible with the database obtained. Overall, the stiffness parameters of peat soil increase significantly with depth governed by the increase in effective stress. Furthermore, the change of decomposition rate with depth and different peat thickness also shows potential influence on the stiffness parameters of peat soil. However, further investigation was required to fully understand the effect of decomposition rate and peat thickness on peat soil stiffness value. Nonetheless, geophysical method provides sustainable investigation method due to its non-intrusive nature for investigation on peat soil.

\section{ACKNOWLEDGEMENT}

The authors would like to thank the Ministry of Education Malaysia for their generous grant of this research, Research Fund E15501, Research Management Centre, Universiti Tun Hussein Onn Malaysia (UTHM), and GPPS grant Vot number H009. The authors also would like to extend their gratitude to Research Centre for Soft Soil (RECESS) for allowing the use of research equipment and facilities.

\section{Nomenclature:}

MASW Multichannel Analysis of Surface Waves

$\mathrm{V}_{\mathrm{s}} \quad$ Shear-wave velocity

$V_{p} \quad$ Primary-wave velocity

$\mathrm{G}_{\max } \quad$ Maximum shear modulus

$\mathrm{E}_{\max } \quad$ Maximum elastic modulus

$\rho \quad$ Bulk density

$v \quad$ Poisson's ratio

\section{REFERENCES}

[1] Abbiss, C.P., Shear wave measurements of the elasticity of the ground. Géotechnique, 1981.31(1): p. 91-104.

[2] Basri, K., Zainorabidin, A., Masirin, M.I.M., Said, M.J.M., and Abdurahman, M.N. Estimation of Shear Wave Velocity Using 1-D Multichannel Analysis of Surface Waves (MASW) and Shear Modulus of Peat. Malaysian Construction Research Journal, 2018. 24(1): p. 1-10.

[3] Foti, S., Small-strain stiffness and damping ratio of Pisa clay from surface wave tests. Geotechnique, 2003. 53(5): p. 455-461.

[4] Szczepanski, T., Soil small strain parameters derived from wave velocity measurements. geologija, 2008.

[5] Matthews, M., V. Hope, and C. Clayton. The use of surface waves in the determination of ground stiffness profiles. in International Journal of Rock Mechanics and Mining Sciences and Geomechanics Abstracts. 1996.

[6] Trafford, A. and M. Long, Relationship between Shear-Wave Velocity and Undrained Shear Strength of Peat. Journal of Geotechnical and Geoenvironmental Engineering, 2020. 146(7): p. 04020057. 
[7] Blake, W. and R. Gilbert. Investigation of possible relationship between undrained shear strength and shear wave velocity for normally consolidated clays. in Offshore Technology Conference. 1997. Offshore Technology Conference.

[8] Agaiby, S.S. and P.W. Mayne. Relationship between undrained shear strength and shear wave velocity for clays. in 6th Symp. on Deformation Characteristics of Geomaterials. 2015. IOS Press, Argentina.

[9] Lu, C.C. and J.H. Hwang, Correlations between Vs and SPT-N by different borehole measurement methods: effect on seismic site classification. Bulletin of Earthquake Engineering, 2019: p. 1-21.

[10] Bitri, A., Samyn, K., Brulé, S., and Javelaud, E.H. Assessment of ground compaction using multichannel analysis of surface wave data and cone penetration tests. Near Surface Geophysics, 2013. 11(6): p. 683-690.

[11] Cai, G., A.J. Puppala, and S. Liu, Characterization on the correlation between shear wave velocity and piezocone tip resistance of Jiangsu clays. Engineering Geology, 2014. 171: p. 96-103.

[12] Mayne, P.W. and G.J. Rix, Correlations between shear wave velocity and cone tip resistance in natural clays. Soils and foundations, 1995. 35(2): p. 107-110.

[13] L'Heureux, J.S. and M. Long. Correlations between shear wave velocity and geotechnical parameters in Norwegian clays. in Proceedings of the 17th Nordic Geotechnical Meeting. 2016.

[14] L'Heureux, J.S. and M. Long, Relationship between Shear-Wave Velocity and Geotechnical Parameters for Norwegian Clays. Journal of Geotechnical and Geoenvironmental Engineering, 2017. 143(6): p. 04017013.

[15] Matthews, M., V. Hope, and C. Clayton, The geotechnical value of ground stiffness determined using seismic methods. Geological Society, London, Engineering Geology Special Publications, 1997. 12(1): p. 113-123.

[16] Zainorabidin, A. and H.M. Mohamad, Engineering Properties of Integrated Tropical Peat Soil in Malaysia. Electronic Journal of Geotechnical Engineering, 2017. 22(02): p. 457-466.

[17] Seed, H.B. and I.M. Idriss, Soil moduli and damping factors for dynamic response analysis. Journal of Terramechanics, 1972. 8(3): p. 109.

[18] Sauvin, G., Vanneste, M., L'Heureux, J.S., O'Connor, P., O'Rourke, S., O'Connell, Y., and Long, M. Impact of data acquisition parameters and processing techniques on $S$-wave velocity profiles from MASW-Examples from Trondheim, Norway. in Proceedings of the 17th Nordic Geotechnical Meeting. 2016.

[19] Jon, D., Usha, M., Sarala, A., Nyon, Y.C., and Gabriel, C. A quick scan of Peatlands in Malaysia. Wetlands International Malaysia, 2010. 1.

[20] Huat, B.B.K., Asadi, A., Prasad, A., and Kazemian, S. Geotechnics of organic soils and peat. 2014: CRC Press.

[21] Basri, K., Wahab, N., Talib, M.K.A., and Zainorabidin, A. Sub-surface Profiling Using Electrical Resistivity Tomography (ERT) with Complement from Peat Sampler. Civil Engineering and Architecture, 2019. 7(6A), p. 7 - 18.

[22] Wahab, N., Talib, M.K.A., Basri, K., and Rohani, M.M. Segregation Peat Fiber and PreConsolidation Pressure Effect on the Physical Properties of Reconstituted Peat Soil. International Journal of Engineering and Advanced Technology (IJEAT), 2019. 8(6S3): p. 640-647.

[23] Huat, B.B.K., Kazemian, S., Prasad, A., and Barghchi, M. State of an art review of peat: General perspective. International Journal of Physical Sciences, 2011. 6(8): p. 1988-1996.

[24] Ulusay, R., E. Tuncay, and N. Hasancebi, Geo-engineering properties and settlement of peaty soils at an industrial site (Turkey). Bulletin of engineering geology and the environment, 2010. 69(3): p. 397-410.

[25] Kazemian, S., Organic Soils and Peats, in Encyclopedia of Engineering Geology. 2017, Springer. p. 1-5.

[26] Park, C.B., R.D. Miller, and J. Xia, Multichannel analysis of surface waves. Geophysics, 1999. 64(3): p. 800-808. 
[27] Basri, K., Talib, M.K.A., Jumien, N.L., Ping, B.P.A., Zainorabidin, A., Madun, A., Pakir, F., and Yusof, M.F. Influence of Source Energy and Stacking on Active MASW Method Dispersion Image. in IOP Conference Series: Earth and Environmental Science. 2020. IOP Publishing.

[28] Basri, K., Talib, M.K.A., Ping, B.P.A., Jumien, N.L., Zainorabidin, A., Lim, A.J.M.S., Dan, M.F.M., and Talib, Z.A. Comparison of Dispersion Image Resolution Acquired Using Multichannel Analysis of Surface Waves with Different Source Energy and Stacking. in IOP Conference Series: Earth and Environmental Science. 2020. IOP Publishing.

[29] Said, M.J.M., A. Zainorabidin, and A. Madun, Data Acquisition Challenges on Peat Soil Using Seismic Refraction, in InCIEC 2014. 2015, Springer. p. 477-486.

[30] Park, C.B. and J. Shawver. MASW survey using multiple source offsets. in Symposium on the Application of Geophysics to Engineering and Environmental Problems 2009. 2009. Society of Exploration Geophysicists.

[31] Roy, N. and R.S. Jakka, Near-field effects on site characterization using MASW technique. Soil Dynamics and Earthquake Engineering, 2017. 97: p. 289-303.

[32] Construction Research Institute of Malaysia, Guidelines for Construction on Peat and Organic Soils in Malaysia. Second edition ed. 2019.

[33] Equipment, E.A., Peat Sampler Operating Instruction. Netherlands: Eijkelkamp Agrisearch Equipment, 2014.

[34] Zainorabidin, A. and S.N.A. Zolkefle, Dynamic Behaviour of Western Johore Peat, Malaysia. APCBEE Procedia, 2014.

[35] Zainorabidin, A. and D.C. Wijeyesekera, Geotechnical challenges with Malaysian peat. Advances in Computing and Technology, 2007: p. 252-261.

[36] Huat, B.B.K., Deformation and shear strength characteristics of some tropical peat and organic soils. Pertanika J. Sci. Technol, 2006. 14(1-2): p. 61-74.

[37] MacCulloch, F., Guidelines for the risk management of peat slips on the construction of low volume/low cost roads over peat. The ROADEX II Project, 2006.

[38] O'Kelly, B.C. and S.P. Pichan, Effects of decomposition on the compressibility of fibrous peat-A review. Geomechanics and Geoengineering, 2013. 8(4): p. 286-296.

[39] Sarkar, G. and A. Sadrekarimi, Compressibility and monotonic shearing behaviour of Toronto peat. Engineering Geology, 2020: p. 105822.

[40] Luo, Y., Xia, J., Liu, J., Xu, Y., and Liu, Q. Research on the middle-of-receiver-spread assumption of the MASW method. Soil Dynamics and Earthquake Engineering, 2009. 29(1): p. 71-79.

[41] Donohue, S., Long, M., O'Connor, P., and Gavin, K. Use of multichannel analysis of surface waves in determining Gmax for soft clay. in Proceedings 2nd. Int. Conf on Geotechnical Site Characterisation, ISC. 2004.

[42] Matthews, M., C. Clayton, and Y. Own, The use of field geophysical techniques to determine geotechnical stiffness parameters. Proceedings of the Institution of Civil Engineers-Geotechnical Engineering, 2000. 143(1): p. 31-42.

[43] Kishida, T., Boulanger, R.W., Wehling, T.M., and Driller, M.W. Variation of small strain stiffness for peat and organic soil. In Proc., 8th US National Conf. on Earthquake Engineering, 2006. 